\title{
OR51E2 Gene
}

National Cancer Institute

\section{Source}

National Cancer Institute. OR51E2 Gene. NCI Thesaurus. Code C132106.

This gene may play a role in olfactory chemosensation. 